\title{
Role of Membrane Potential and ATP in Complex Formation between Escherichia coli Male Cells and Filamentous Phage fd
}

\author{
By MITSUYO YAMAMOTO, SHIRO KANEGASAKI* AND \\ MASANOSUKE YOSHIKAWA \\ Institute of Medical Science, University of Tokyo, 4-6-1 Shirokanedai Minato-ku, \\ Tokyo 108, Japan
}

(Received 21 August 1980; revised 30 October 1980)

\begin{abstract}
Mutant strains of Escherichia coli male cells defective in $\mathrm{Ca}^{2+}, \mathrm{Mg}^{2+}$-dependent ATPase (unc) were constructed and tested for their ability to form a complex between sex pili and the filamentous phage fd under conditions where either the membrane potential or the cellular concentration of ATP was lowered. The uncoupler carbonyl cyanide $m$-chlorophenylhydrazone and the respiratory inhibitor cyanide, as well as valinomycin- $\mathrm{K}^{+}$and colicin $\mathrm{E} 1$, all markedly diminished complex formation, indicating that the maintenance of a membrane potential, but probably not the $\mathrm{pH}$ gradient, is essential for the formation of the complex. Since complex formation with freshly centrifuged cells (which initially lacked sex pili) as well as with preincubated cells (in which pre-existing pili were available for complex formation) was inhibited by exposure to the inhibitors, energy seems to be required for both the reappearance (probably assembly) and the maintenance of sex pili on the cell surface. Brief exposure of freshly centrifuged cells to arsenate resulted in only partial inhibition of complex formation. However, marked inhibition of complex formation was observed following exposure to arsenate ot preincubated cells possessing sex pili. This indicates that compounds such as ATP may also be required for maintenance of sex pili on the cell surface.
\end{abstract}

\section{INTRODUCTION}

Extensive genetic analysis (Achtman, 1973; Tomoeda et al., 1975; Rowbury, 1977) has shown that sex pili play an essential role in bacterial conjugation and in infection by specific phages. However, the precise function and the mechanism of assembly and maintenance of sex pili are still not understood. We have previously shown that the formation of a complex between Escherichia coli male cells and the filamentous phage fd was greatly reduced by various energy inhibitors, uncouplers and arsenate (Yamamoto et al., 1980). In the same paper, we demonstrated that lowering the cellular ATP concentration by a temperature shift was accompanied by reduced ability to form the complex.

In our previous studies (Yamamoto et al., 1980), the formation of the complex itself was not found to be energy dependent and proceeded even at $0^{\circ} \mathrm{C}$. Since complex formation was prevented by addition of inhibitors to male cells which possessed pili or to cells which had been stripped of sex pili by centrifugation, we concluded that a source of energy was necessary for the reappearance and maintenance of sex pili on the cell surface. Reappearance of sex pili was only partially prevented by chloramphenicol, suggesting that it represented mainly reassembly rather than resynthesis, but energy inhibitors still reduced complex formation in the presence of chloramphenicol, indicating that the assembly was energy dependent. A similar conclusion was also drawn by Novotny et al. (1972) and O'Callaghan et al. (1973), based on electron microscopic observations of sex pili. Since inhibition of complex formation 
by uncouplers or arsenate was not reversed by the addition of glucose or D-lactate, respectively, it was suggested that the energy was not supplied solely by ATP from glycolysis or by electron transport derived from the D-lactate system (Larsen et al., 1974; Yamamoto et al., 1980).

In this report the source of energy for functioning sex pili, which can be assayed by complex formation between male cells and filamentous phage fd, was investigated using $E$. coli male cells defective in the $\mathrm{F}_{0}$ or $\mathrm{F}_{1}$ portion of the $\mathrm{Ca}^{2+}, \mathrm{Mg}^{2+}$-dependent ATPase (unc mutants: Cox et al., 1973). Such bacteria have a lowered membrane potential without an accompanying lowering of the cellular ATP concentration (Plate et al., 1974; Plate, 1979) when treated with uncouplers, valinomycin or colicin E1. Our results suggest that the maintenance of a membrane potential is essential for the formation and maintenance of sex pili.

\section{METHODS}

Bacteria and phage. Escherichia coli $\mathrm{K} 12$ strain YC233 (a met derivative of W1895 Hfr) was used as the parental male strain (Yamamoto et al., 1980). An uncB derivative (YM-22) of this strain was isolated after phage P1 transduction with strain YC233-8 (an ilv derivative of YC233) as recipient and E. coli strain AN382 (argE3, thi, str, uncB401) as donor. Strain YC233-8 (ilv) was isolated after $N$-methyl- $N^{\prime}$-nitro- $N$-nitrosoguanidine (50 $\mu \mathrm{g}$ $\mathrm{ml}^{-1}$ ) treatment of YC233 followed by penicillin screening. Strain AN382 was kindly provided by F. Gibson, Australian National University, Canberra, Australia. UncA and uncB mutants carrying Flac (YM-11 and YM-21) were prepared by transfer of Flac to E. coli KY2377 (lac-1, gal-1, gal-2, tonB, uncA401) and E. coli OK 101 (lac-1, gal-1, tonB, uncB402). Strains OK 101 and KY2377 were kindly provided by M. Futai, Okayama University, Okayama, Japan. Since we observed frequent reversion of uncB mutants, a single colony, which we used as the source of the culture in each experiment, was checked to determine if it grew in M9 medium with succinate as sole carbon source. Filamentous phage fd was labelled with $\mathrm{H}_{2}{ }^{35} \mathrm{SO}_{4}$ as described by Yamamoto $e t a l$. (1980).

Filtration assay of fd complex formation. This was done as described previously (Yamamoto et al., 1980). ${ }^{35}$ S-labelled phage fd $\left[5000 \text { to } 12000 \text { c.p.m., approximately } 5.0 \times 10^{4} \text { plaque forming units (c.p.m. }\right)^{-1}$ in a fresh preparationl was added to $0.2 \mathrm{ml}$ cell suspension, and the mixture was incubated under the conditions described in the figure legends. The mixture was filtered through a cellulose acetate filter (Gelman Metricel GA6), the filter was

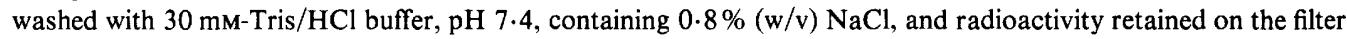
was counted. In general, complex formation was assayed using centrifuged cells, most of which initially did not possess sex pili. Sex pili appeared during the incubation at $37^{\circ} \mathrm{C}$ (Yamamoto et al., 1980). Therefore, addition of reagents to this system should affect the assembly or maintenance of sex pili or both. Preincubation of centrifuged cells at $37^{\circ} \mathrm{C}$ resulted in extension from the cells of pili ready to be used for complex formation. Complex formation between fd and pre-existing pili occurred even at $0^{\circ} \mathrm{C}$. In order to determine the effect of reagents on the maintenance (or functional activity) of sex pili, therefore, the reagents were added at the end of preincubation and complex formation was assayed at $0^{\circ} \mathrm{C}$. Complex formation is expressed as the percentage of phage retained on the filter based on the radioactivity added to the reaction mixture as $100 \%$.

Valinomycin treatment. Following the basic methods of Szmelcman \& Adler (1976) and Plate (1979), bacteria grown in L-broth to a concentration of about $1.6 \times 10^{9}$ cells $\mathrm{ml}^{-1}$ were harvested by centrifugation and washed with $0.1 \mathrm{M}-\mathrm{Tris} / \mathrm{HCl}, \mathrm{pH} 7.8$. The pellets were resuspended in $1 \mathrm{ml}$ of the same buffer. After keeping the suspension for $6 \mathrm{~min}$ at $37^{\circ} \mathrm{C}, \mathrm{Na}_{2} \mathrm{EDTA}(10 \mathrm{mM}) /$ Tris $(15 \mathrm{mM}), \mathrm{pH} 8.0$, was added and incubation was continued for a further $3 \mathrm{~min} ; 10 \mathrm{ml}$ ice-cold $0.1 \mathrm{M}$-sodium phosphate buffer $(\mathrm{pH} \mathrm{7.2)}$ was then added to the reaction tubes, and the mixtures were centrifuged. The bacteria were suspended in $3 \mathrm{ml} 10 \mathrm{mM}$-sodium phosphate buffer, $\mathrm{pH} 7 \cdot 2$, containing $0.1 \mathrm{M}-\mathrm{NaCl}$, and then mixed with the same volume of $10 \mathrm{mM}$-sodium phosphate buffer, $\mathrm{pH} 7.2$, supplemented with $22 \mathrm{~mm}$-glucose, $20 \mathrm{~mm} \mathrm{MgSO}_{4}, 40 \mathrm{~mm}-\mathrm{K}^{+}$(as potassium phosphate buffer), $0 \cdot 1 \mathrm{M}-\mathrm{NaCl}$ and $10 \mu \mathrm{M}$-valinomycin. The reaction mixture without valinomycin was used as a control. The final suspension was incubated with shaking at $27^{\circ} \mathrm{C}$ for 4 min and kept in ice until used.

Assay of cellular ATP concentration. ATP concentration was measured by the luciferin-luciferase assay (Lundin \& Thore, 1975) as described by Yamamoto et al. (1980). Bacterial suspensions (0.5 ml) were mixed with $2 \mathrm{ml}$ boiling buffer ( $20 \mathrm{mM}$-Tris/ $\mathrm{HCl}$ containing $2 \mathrm{mM}$-EDTA), and the mixture was boiled for $90 \mathrm{~s}$ to extract ATP. A portion of boiled solution $(0.5 \mathrm{ml})$ was mixed with $0.2 \mathrm{ml}$ of the firefly extract solution and light emission was recorded using a Bioluminescence reader (BLR-101C; Aloka Co., Tokyo, Japan). Protein was determined by the Lowry method using bovine serum albumin as a standard. 


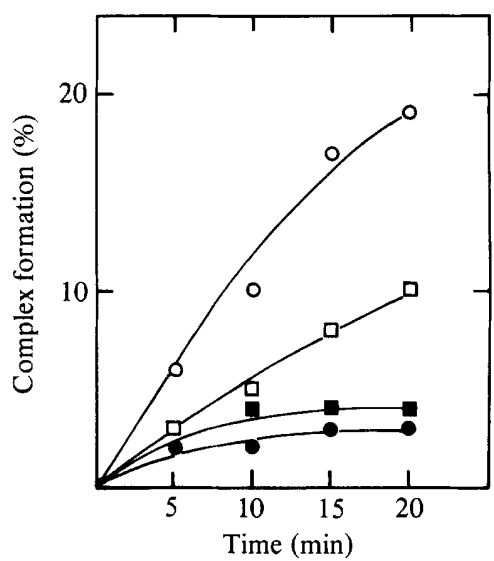

Fig. 1

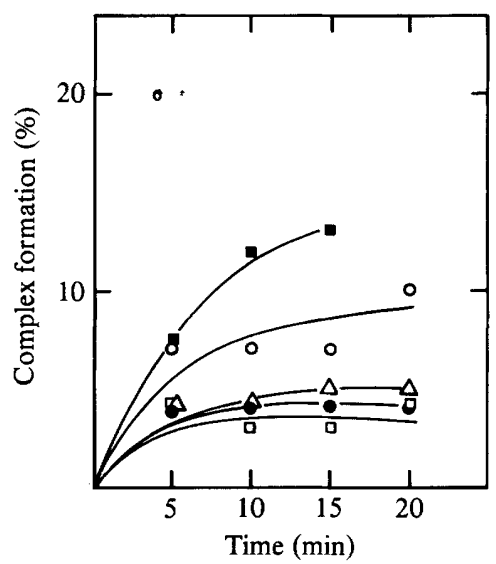

Fig. 2

Fig. 1. Effect of CCCP and arsenate on complex formation between phage fd and centrifuged cells of strain YM-22 (uncB Hfr). A suspension of centrifuged cells $\left(3.5 \times 10^{8}\right.$ in $0.2 \mathrm{ml} \mathrm{L}$-broth, see Methods) was first treated for $3 \mathrm{~min}$ with either CCCP (final concentration $50 \mu \mathrm{M}, \square$ ) or arsenate (final concentration $10 \mathrm{mM}, \square)$, or left untreated $(\mathrm{O}, \bigcirc)$, and then mixed with ${ }^{35} \mathrm{~S}$-labelled phage fd $(15 \mu \mathrm{l}$, 5700 c.p.m.) and incubated at $37^{\circ} \mathrm{C}(\square, \square, 0)$ or $0^{\circ} \mathrm{C}(O)$ for the indicated periods. Complex formation was assayed by filtration as described in Methods.

Fig. 2. Complex formation at $0^{\circ} \mathrm{C}$ between phage fd and preincubated cells of strain YM-22 (uncB $\mathrm{Hfr})$. A suspension of centrifuged cells $\left(3.5 \times 10^{8} \mathrm{in} 0.2 \mathrm{ml} \mathrm{L}\right.$-broth) was incubated at $37^{\circ} \mathrm{C}$ for $27 \mathrm{~min}$ and then treated for $3 \mathrm{~min}$ with either CCCP (final concentration $50 \mu \mathrm{M}$, $\square$ ) or arsenate (final concentration $10 \mathrm{mM}, \triangle$ ), or left untreated (O). After cooling for $3 \mathrm{~min}$ in an ice-water bath the suspension was mixed with ${ }^{35} \mathrm{~S}$-labelled phage fd $\left(10 \mu \mathrm{l}, 10000\right.$ c.p.m.) and incubated at $0{ }^{\circ} \mathrm{C}$ for the indicated periods. Complex formation was assayed as described in Methods. For comparison, complex formation of non-preincubated cells at $37^{\circ} \mathrm{C}(\boldsymbol{\nabla})$ and at $0{ }^{\circ} \mathrm{C}(\mathrm{O})$ is also shown.

Chemicals. Purified colicin E1 was a gift from A. Nakazawa, Yamaguchi University, Ube, Japan. Valinomycin and carbonyl cyanide $m$-chlorophenylhydrazone (CCCP) were obtained from Sigma. Firefly lantern extract and ATP were obtained from Calbiochem. All other chemicals used were reagent grade.

\section{RESULTS}

Complex formation between male cells defective in $\mathrm{Ca}^{2+}, \mathrm{Mg}^{2+}$-dependent ATPase (unc) and filamentous phage $f d$. Hfr bacteria defective in the $u n c B$ gene, and $u n c A$ or $u n c B$ mutants carrying Flac were constructed as described in Methods and tested for complex formation with ${ }^{35}$ S-labelled phage fd. Slightly less complex was observed with the unc derivatives as compared with the wild-type parent.

Effect of CCCP and cyanide on complex formation between unc male cells and phage fd. Uncouplers of oxidative phosphorylation are known to deplete the energized membrane state. In a previous paper (Yamamoto et al., 1980), we showed that such uncouplers inhibited complex formation between $E$. coli male cells and phage fd. Using unc mutants (uncB $\mathrm{Hfr}$, $u n c A$ Flac and $u n c B$ Flac strains), in which the energized membrane state depends solely on electron transport and not on ATP hydrolysis mediated by ATPase (Harold, 1977), we confirmed that the uncoupler CCCP inhibited complex formation at $37^{\circ} \mathrm{C}$ (Fig. 1) when added to freshly centrifuged bacteria without preincubation. Similar results were obtained using the respiratory inhibitor $\mathrm{NaCN}$. The results suggest that reappearance of sex pili requires the energized membrane state.

Even brief $(3 \mathrm{~min})$ exposure to $\mathrm{CCCP}$ at $37^{\circ} \mathrm{C}$ at the end of the preincubation of the bacteria diminished subsequent complex formation measured at $0^{\circ} \mathrm{C}$ (Fig. 2). Again, similar results were obtained with $\mathrm{NaCN}$. The results indicate that sex pili extended from the cell surface during preincubation (Yamamoto et al., 1980) but were quickly lost upon exposure to 


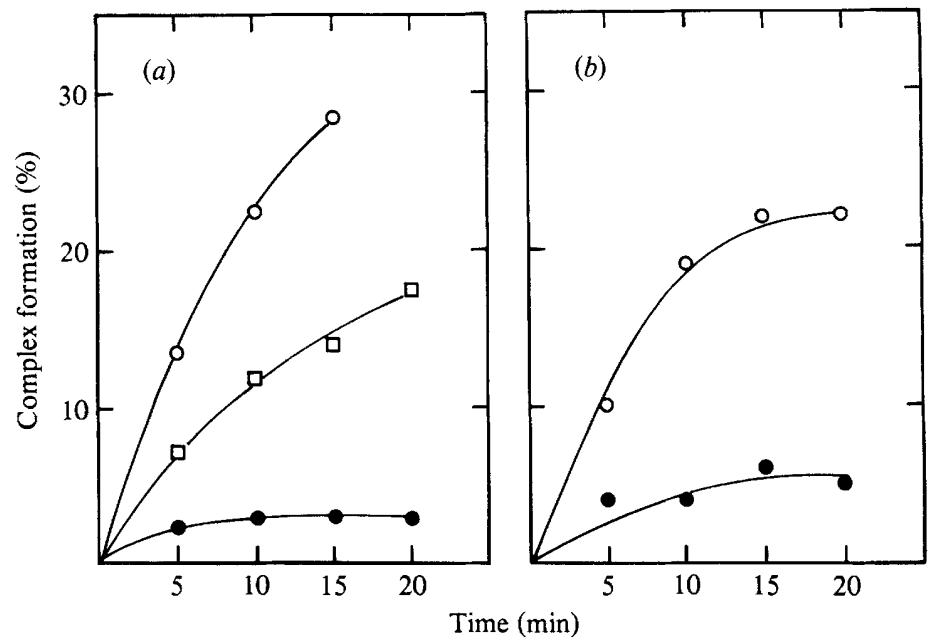

Fig. 3. Complex formation between phage fd and valinomycin-treated cells of $(a)$ strain YC233 $\left(u n c^{+}\right)$ and $(b)$ strain YM-22 (uncB Hfr). A suspension of cells $\left(8 \times 10^{8}\right.$ in $\left.0.2 \mathrm{ml}\right)$ which had been treated with valinomycin (see Methods) in the presence $(O)$ or absence $(\square)$ of $\mathrm{K}^{+}$, or left untreated $(\bar{O})$, was mixed with ${ }^{35}$ S-labelled phage fd $(15 \mu \mathrm{l}, 7600$ c.p.m. $)$ and incubated at $37^{\circ} \mathrm{C}$ for the indicated periods. Complex formation was assayed as described in Methods.

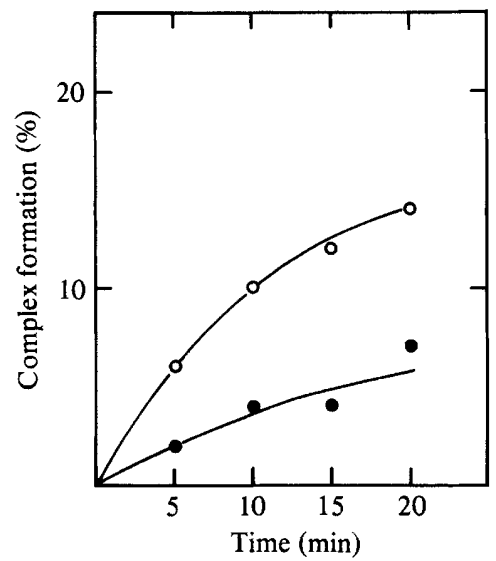

Fig. 4. Effect of colicin E1 on complex formation between phage fd and centrifuged cells of strain YM-22 (uncB Hfr). A suspension of centrifuged cells $\left(3.5 \times 10^{8}\right.$ in $0.2 \mathrm{ml}$ L-broth) was mixed with $40 \mu \mathrm{l}$ of either colicin E1 $(10 \mu \mathrm{g} \mathrm{ml}-1$, purity $80 \%$; $)$ or water $(\mathrm{O})$, and then ${ }^{35} \mathrm{~S}$-labelled phage fd $\left(10 \mu \mathrm{l}, 12000\right.$ c.p.m.) was added and the mixture was incubated at $37^{\circ} \mathrm{C}$ for the indicated periods. Complex formation was assayed as described in Methods.

the uncoupler or the respiratory inhibitor, i.e. maintenance of sex pili required the energized membrane state.

Effect of valinomycin and colicin E1 on complex formation between unc male cells and phage $f d$. Valinomycin, in the presence of $\mathrm{K}^{+}$, is known to lower the membrane potential without affecting the $\mathrm{pH}$ gradient established in the bacteria (Ramos \& Kaback, 1977). Colicin E1 also induces membrane depolarization by increasing the permeability to ions (Tokuda \& Konisky, 1978, 1979). We therefore tested whether these agents inhibited complex formation at $37^{\circ} \mathrm{C}$ between phage fd and unc derivatives of an Hfr strain or unc mutants which possessed Flac. 


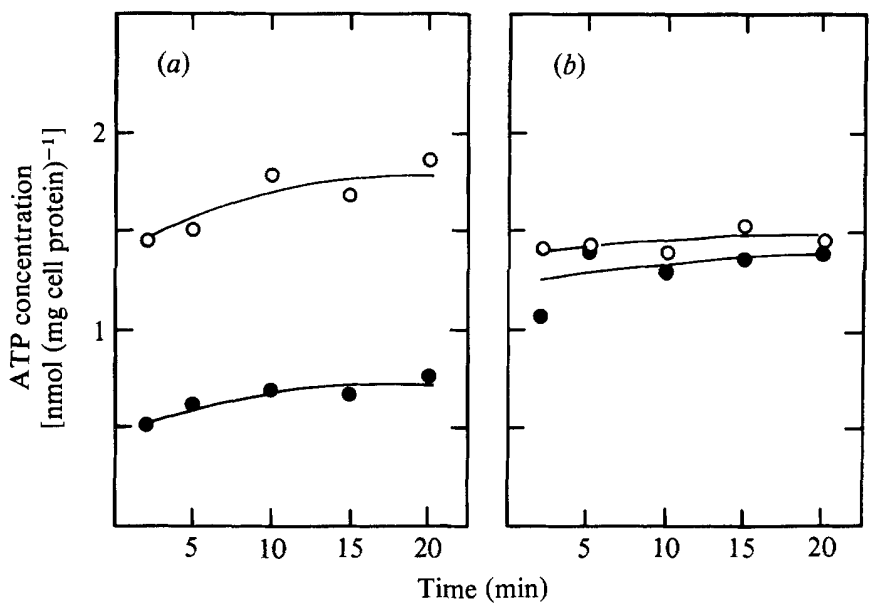

Fig. 5. Effect of valinomycin on the cellular ATP concentrations of (a) strain YC233 (unc $\left.{ }^{+}\right)$and (b) strain YM-22 (uncB Hfr). A suspension $(0.5 \mathrm{ml})$ of valinomycin-treated (O) or untreated (O) cells was incubated at $37^{\circ} \mathrm{C}$ for the indicated periods. Cellular ATP concentrations were assayed as described in Methods.

As shown in Fig. 3, addition of valinomycin in the presence of $20 \mathrm{~mm}-\mathrm{K}^{+}$to freshly centrifuged, EDTA-treated $u n c B$ Hfr bacteria significantly reduced complex formation, as observed with the parental strain. Similar results were also obtained with other unc derivatives of male strains. Colicin E1 also inhibited complex formation (Fig. 4). The cellular ATP concentrations of an $u n c B$ Hfr strain and the parental strain treated with valinomycin are shown in Fig. 5. The ATP concentration in unc mutants was either only slightly lowered or not affected compared with that in wild-type strains in all cases tested. These results indicate that the maintenance of a membrane potential, but probably not the $\mathrm{pH}$ gradient, is essential for the reappearance of sex pili.

Effect of arsenate on complex formation in the unc strains. Arsenate is known to lower cellular ATP concentrations drastically (Klein \& Boyer, 1972). If the membrane potential is the only source of energy for functioning sex pili, complex formation should be relatively resistant to arsenate. As shown in Fig. 1, arsenate partially inhibited complex formation between freshly centrifuged unc Hfr bacteria and phage fd. The effect of arsenate was also studied using preincubated cells in which sex pili were already induced and ready to use for complex formation. Addition of arsenate at the end of preincubation resulted in a marked reduction of complex formation (Fig. 2), suggesting that, in addition to changes in membrane potential, decreased cellular ATP concentrations also influenced the maintenance of sex pili.

\section{DISCUSSION}

In our previous paper (Yamamoto et al, 1980), we showed that the ability of $E$. coli male cells to form a complex with phage fd depended on the number of sex pili observed on the cell surface and that complex formation itself was not energy dependent and proceeded even at $0^{\circ} \mathrm{C}$. Thus, the extent of complex formation reflects the number of functioning sex pili on the cell surface. In the present study, we have shown that complex formation between $E$. coli male cells deficient in $\mathrm{Ca}^{2+}, \mathrm{Mg}^{2+}$-dependent ATPase (unc) and filamentous phage fd was inhibited strongly by exposure of freshly centrifuged bacteria to the uncoupler CCCP, the respiratory inhibitor $\mathrm{NaCN}$, valinomycin- $\mathrm{K}^{+}$and colicin $\mathrm{E} 1$. In contrast, complex formation was only partially inhibited by arsenate. Little or no diminution in the cellular ATP concentration of the unc mutants was produced by exposure to the inhibitors other than arsenate, whereas 
drastic lowering was observed in the presence of arsenate (results not shown). In the parental strain, the ATP concentration was lowered to 30 to $50 \%$ of normal by uncouplers or by $\mathrm{NaCN}$ and to less than $3 \%$ by arsenate (Yamamoto et al., 1980). These results indicate that the energized membrane state is a major requirement for the formation of functionally active sex pili capable of forming a complex with phage $\mathrm{fd}$. The maintenance of a membrane potential, but not the $\mathrm{pH}$ gradient, appears to be essential since valinomycin- $\mathrm{K}^{+}$and colicin E1 were both as effective as CCCP in inhibiting eventual complex formation.

Complex formation between preincubated cells and phage fd was also inhibited by subsequent depletion of the membrane potential or by lowering of cellular concentrations of ATP (and possibly of related so-called 'high-energy compounds'). The preincubated cells acquired sex pili on the cell surface, apparently ready for complex formation. This was in contrast to freshly centrifuged bacteria, which initially did not possess sex pili and failed to form the complex. These results indicate that both the membrane potential and compounds such as ATP are required for keeping functionally active sex pili on the cell surface. However, we cannot define at the moment how the energy is used in maintaining sex pili.

It is unlikely that the prevention of complex formation represents side effects of the reagents used, since they did not alter complex formation at $0{ }^{\circ} \mathrm{C}$, indicating that the compounds had no direct effect on sex pili (Yamamoto et al., 1980).

We conclude that in the earliest step of filamentous phage infection, the host bacteria must maintain an energized membrane state in order to keep sex pili on the bacterial surface. Sex pili seem to extend from the inner membrane, probably at the place where the inner and outer membranes are joined together (Bayer, 1975); this presumably allows phage adsorbed to the tip of pili (Caro \& Schnös, 1966) subsequently to reach the cell surface where single-stranded DNA is introduced into the bacteria. In bacterial conjugation, a source of energy appears to be essential in both male and female cells in order to accomplish DNA transfer and, at least in female cells, this was reported to be the proton-motive force (Grinius \& Beržinskienè, 1976).

The authors thank Drs Iwao Kato and Yoshito Kaziro for their encouragement. This study was supported in part by a grant-in-aid for scientific research from the Ministry of Education, Science and Culture, Japan. M.Y. is a recipient of the Fellowship of the Miyata-Senji Association for the Advancement of Science.

\section{REFERENCES}

Achtman, M. (1973). Genetics of the F sex factor in Enterobacteriaceae. Current Topics in Microbiology and Immunology 60.79-123.

BAYER, M. E. (1975). Role of adhesion zones in bacterial cell-surface function and biogenesis. In Membrane Biogenesis: Mitochondria, Chloroplasts and Bacteria, pp. 393-424. Edited by A. Tzagoloff. New York: Plenum Press.

CARo, L. G. \& Schnös, M. (1966). The attachment of the male specific bacteriophage 1 to sensitive strains of Escherichia coli. Proceedings of the National Academy of Sciences of the United States of America 56, 126-132.

Cox, G. B., Gibson, F. \& McCanN, L. (1973). Reconstitution of oxidative phosphorylation and the adenosine triphosphate-dependent transhydrogenase activity by a combination of membrane fractions from $u n c A^{-}$and $u n c B^{-}$mutant strains of Escherichia coli K12. Biochemical Journal 134, 1015-1021.

Grinius, L. \& Beržinskienė, J. (1976). Studies on DNA transport during bacterial conjugation. Role of proton motive force-generating $\mathrm{H}^{+}$-ATPase and respiratory chain. FEBS Letters 72 , 151-154.
HAROLD, F. M. (1971). Membranes and energy transduction in bacteria. Current Topics in Bioenergetics 6, 83-149.

KLEIN, W. L. \& BoYER, P. D. (1972). Energization of active transport by Escherichia coli. Journal of Biological Chemistry 247, 7257-7265.

Larsen, S. H., Adler, J., Gargus, J. J. \& Hogg, R. W. (1974). Chemomechanical coupling without ATP: the source of energy for motility and chemotaxis in bacteria. Proceedings of the National Academy of Sciences of the United States of America 71, 1239-1243.

LUNDIN, A. \& ThORE, A. (1975). Analytical information obtainable by evaluation of the time course of firefly bioluminescence in the assay of ATP. Analytical Biochemistry 66, 47-63.

Novotny, C. P., TAYlor, P. F. \& Levin, K. (1972). Effects of growth inhibitors and ultraviolet irradiation on $\mathrm{F}$ pili. Journal of Bacteriology 112 , 1083-1089.

O'Callaghan, R. J., Bundy, L., Bradley, R. \& PARANCHYCH, W. (1973). Unusual arsenate poisoning of the $\mathrm{F}$ pili of Escherichia coli. Journal of Bacteriology 115, 76-81. 
Plate, C. A. (1979). Requirement for membrane potential in active transport of glutamine by Escherichia coli. Journal of Bacteriology 137, 221-225.

Plate, C. A., Suit, J. L., Jetten, A. M. \& Luria, S. E. (1974). Effects of colicin $K$ on a mutant of Escherichia coli deficient in $\mathrm{Ca}^{2+}, \mathrm{Mg}^{2+}$-activated adenosine triphosphatase. Journal of Biological Chemistry 249, 6138-6143.

Ramos, S. \& KaBACK, H. R. (1977). The electrochemical proton gradient in Escherichia coli membrane vesicles. Biochemistry 16, 848-853.

RowBURY, R. J. (1977). Bacterial plasmids with particular reference to their replication and transfer properties. Progress in Biophysics and Molecular Biology 31, 271-317. ;;

Szmelcman, S. \& AdLer, J.' (1976). Changes in membrane potential during bacterial chemotaxis. Proceedings of the National Academy of Sciences of the United States of America 73, 43874391.

TokUdA, H. \& KonISKy, J. (1978). Mode of action of colicin Ia: effect of colicin on the Escherichia coli proton electrochemical gradient. Proceedings of the National Academy of Sciences of the United States of America 75, 2579-2583.

TOKUDA, H. \& KONISKY, J. (1979). Effects of colicins Ia and E1 on ion permeability of liposomes. Proceedings of the National Academy of Sciences of the United States of America 76, 6167-6171.

Tomoeda, M., InuzuKA, M. \& DATE, T. (1975). Bacterial sex pili. Progress in Biophysics and Molecular Biology 30, 23-56.

YAMAMoto, M., Kanegasaki, S. \& Yoshikawa, M. (1980). Effects of temperature and energy inhibitors on complex formation between Escherichia coli male cells and filamentous phage fd. Journal of General Microbiology 119, 87-93. 
